\title{
Zeolite pretreatment accomplishes partial brain radioprotective role by reducing iron and oxidative / nitrosative stress in rats
}

\author{
Boban Stanojević ${ }^{1}$, Mirjana Đukić ${ }^{2 *}$, Ivana \\ Stevanovićs, Milica Ninković3, Ana Đurić2 \\ Borko Gobeljić2, Milan Apostolović, ${ }^{4}$ Ana \\ Pantelićs ${ }^{\text {, Goran Zebić }}{ }^{\text {, Lidija Todorović }}$, \\ Tijana Bojićn, Kiril Savovski ${ }^{1}$ \\ ${ }^{1}$ Department for Radiobiology and Molecular \\ Genetics 080, Institute of Nuclear Sciences "Vinča", \\ University of Belgrade, Belgrade, Serbia \\ ${ }^{2}$ Department of Toxicology, Faculty of Pharmacy, \\ University of Belgrade, Belgrade, Serbia \\ ${ }^{3}$ Institute for Medical Research, Military Medical \\ Academy, Medical Faculty MMA, University of \\ Defense, Belgrade, Serbia \\ ${ }^{4}$ University of Belgrade - School of Medicine, \\ Institute for Orthopedic-Surgical diseases "Banjica" \\ ${ }^{5}$ Department of Chemistry, Scientific Institution, \\ Institute of Chemistry, Technology and Metallurgy, \\ University of Belgrade, Studentski trg 12-16, 11000 \\ Belgrade, Serbia \\ ${ }^{6}$ Department for Food Technology, Faculty of \\ Agriculture, University of Belgrade, Nemanjina 6, \\ 11080 Belgrade-Zemun, Serbia \\ * Corresponding author: \\ Mirjana Đukić, PhD, Professor \\ Department of Toxicology, Faculty of Pharmacy, \\ University of Belgrade, Vojvode Stepe 450, 11221 \\ Belgrade, Serbia, e-mail: mirjana.djukic.cipa@ \\ gmail.com; mirjana.djukic@pharmacy.bg.ac.rs \\ Phone (office): +381 113951308 \\ Fax (office): +381 113972840
}

\begin{abstract}
The aim of our study was to test the effect of subacutely applied micronized zeolite [micronized clinoptilolite (MZC)] on brain status of iron ( $\mathrm{Fe}$ ), reactive oxygen and nitrogen species (ROS, RNS), and radioprotective role against brain oxidative/nitrosative stress (OS/NS) initiated by single ionizing radiation of 2 or 10Gray (Gy).

Wistar rats on normal $(n=18)$ and $5 \%$ MZC supplemented diet ( $n=18)$, during 4 weeks, were internally subdivided into 3 subgroups (6 rats in each subgroup), with one of subgroup remaining as a control, and the other two subjected to single ionizing radiation of $2 \mathrm{~Gy}$ or $10 \mathrm{~Gy}$. Thus, we had groups on normal diet: $C$ - controls, 2Gy and 10Gy; and on 5\% MZC supplemented diet: $M Z C, M Z C+2 G y$ and MZC+10Gy. Concentrations of nitrates (a final RNS metabolite) and superoxide anion radical $\left(\mathrm{O}_{2}^{-}\right.$) (an initial ROS) were measured in homogenates of selective vulnerable brain regions (cerebellum, hippocampus and forebrain cortex), while Fe was determined in whole brain of rats. Results documented a significant drop of Fe in MZC and MZC+2Gy/10Gy groups; decrease of $\mathrm{O}_{2}{ }^{--}$and nitrate in MZC group; almost equal drop of $\mathrm{O}_{2}^{--}$, in 2Gy and $\mathrm{MZC}+2 \mathrm{~Gy}$ groups; and nitrate increase in 10Gy and $M Z C+10 G y$ groups. We confirmed that subacute MZC pretreatment contributes to partially accomplished brain radioprotective effect in rats exposed to single radiation dose of $2 \mathrm{~Gy}$ and $10 \mathrm{~Gy}$, probably due to reduced OS/NS and Fe.
\end{abstract}

Key words: brain, iron, ionizing radiation, nitrosative stress, oxidative stress, zeolite (MZC)

\section{INTRODUCTION}

Zeolite, a natural clinoptilolite, is a strong non-selective adsorbent and/or ion exchange agent for different compounds, including metals, mycotoxins, some strains of bacteria, gases, essential nutrients, etc. [1-3]. Adsorptive potential of zeolite grows with the decrease of particle size, which is why we used micronized clinoptilolite (MZC).

Taken orally, zeolite remains intact within the alimentary tract. It is used worldwide as a supplement for animal feed and in human medicine [4] . However, there is plenty of evidence (pro and contra) regarding daily intake of zeolite in humans [5].

In respect to its binding properties, zeolite reduces bioavailability of essential transition metals (iron (Fe), copper $(\mathrm{Cu})$, manganese $(\mathrm{Mn})$, etc., which contribute to free radical production through Fenton like reactions). Also, zeolite absorbs gases released during food fermentation within the alimentary tract (oxygen $\left(\mathrm{O}_{2}\right)$ and nitric oxide (NO), which altogether indicates the certainty of its antioxidative role [6]. Homeostasis of essential metals is particularly important for regular development and physiological functioning of living organisms [7]. Iron is the most abundant transition element in humans with ascertained physiological importance. Nevertheless, Fe contributes to oxidative stress (OS) development, via Fenton reaction, where it reacts with hydrogen peroxide $\left(\mathrm{H}_{2} \mathrm{O}_{2}\right)$ to form the potent hydroxyl radical (HO') [8]. Reactive oxygen and nitrogen species (ROS, RNS) affect all classes of biomolecules (proteins, lipids and DNA), also, they alter cell signaling pathways, gene expression deplete energy and eventually, lead cells into death by apoptosis [9]. 
It is well known that ionizing radiation induces OS in living organisms [10]. We supposed that nitrosative stress (NS) will develop in irradiated rats as well, based on the fact that blood vessel endothelium produces NO which spontaneously reacts with superoxide anion radical $\left(\mathrm{O}_{2}{ }^{--}\right)$and produces harmful RNS, peroxynitrite anion $\left(\mathrm{ONOO}^{-}\right)$. The final metabolic products of entirely generated RNS are nitrates $\left(\mathrm{NO}_{3}^{-}\right)$[9]. Additionally, we assumed that reduced bioavailability of $\mathrm{Fe}, \mathrm{NO}$ and $\mathrm{O}_{2}$ from gastrointestinal tract (GIT) during prolonged MZC intake will result in systemic OS and NS decrease, including brain. Since previous studies confirmed that ionizing radiation causes increase of OS and NS [11, $12]$, we were tempted to check if the prolonged MZC pretreatment will have a radioprotective role in the brain , by analyzing certain OS/NS parameters in rats.

The use of zeolite as a food supplement is based on its detoxification capabilities due to ability to bind various toxins within the GIT [13-15]. Furthermore, zeolite improves some physiological occurrences in treated animals, such as growth improvement, reproductive performance, boosts immune system, etc. [16-18].

Accordingly, the aim of our study was to test if oral pretreatment with $5 \% \mathrm{MZC}$, for 4 weeks, will make any influence on brain status of $\mathrm{Fe}, \mathrm{ROS}$ and RNS and additionally, will radioprotective role against brain OS/NS initiated by single ionizing radiation doses, 2Gray (Gy) or 10Gy, will be attained.

\section{MATERIALS AND METHODS}

\section{Experimental animals}

Adult male Wistar rats (weighing 220-250g) were kept under standardized housing conditions (temperature $23 \pm 2^{\circ} \mathrm{C}$, lighting 12:12 light:dark, light on from 8:00 to 20:00h) with free access to tap water and a custom pellet rat diet. Suspension of MZC was administered daily by gavage. The experimental protocol followed the "Guide for the Care and Use of Laboratory Animals" [19] and was approved by Ethical Committee for Experimental Animals, „Vinča” Institute (No. 6/12).

\section{Experimental design}

Wistar rats on normal diet were randomly subdivided into three groups $(n=6)$ : $C$ - control (not treated) and $2 \mathrm{~Gy}$ and $10 \mathrm{~Gy}$ groups - rats subjected to a single dose of radiation of $2 \mathrm{~Gy}$ or $10 \mathrm{~Gy}$, respectively; and accordingly, rats on $5 \% \mathrm{MZC}$ supplemented diet covered three groups $(n=6)$ : MZC, MZC+2Gy and MZC+10Gy groups. The MZC amount was calculated in respect to the quantity of ingested food and rat body mass. The suspension of $0.85-1 \mathrm{~g}$ of MZC/day (corresponds to $5 \%$ of 17-20 g of custom pellet/day) was administered orally, by gavage, during four weeks [5]. The animals gained $133.85 \pm 24.7 \mathrm{~g}$ body weight after 4 weeks. No statistically differences were observed between the $C$ and MZC groups.
Gamma irradiation of rats was performed in the Laboratory of Radiation Chemistry and Physics, Vinča Institute of Nuclear Sciences, using ${ }^{60} \mathrm{Co}$ gamma source designed for radiobiological and radiation chemistry experiments. The animals were confined in custom made individual cages, made of wire, sideways positioned to the irradiation source and then subjected to the whole body irradiation at a dose rate of $0.167 \mathrm{~Gy} /$ min for 12 minutes (corresponds to a total sublethal dose of $2 \mathrm{~Gy}$ ) or 60 minutes (corresponds to a total lowered lethal dose of 10Gy) [20]. Five days after the irradiation, the animals were anesthetized with a $50 \mathrm{mg}$ of sodium pentobarbital/kg injection before being sacrificed (by decapitation), when brains were removed immediately and stored at $-80{ }^{\circ} \mathrm{C}$, until analyzing. The impact of the administered anesthesia on OS and NS parameters measured in brain of rats was not achieved (the results of intact and anesthetized animals were almost identical, therefore, were not presented).

\section{Reagents}

All reagents and chemicals were of analytical grade or higher purity. In this study we used ethylenediaminetetraacetic acid - EDTA, nitrobluetetrazolium - NBT, nitric acid - $\mathrm{HNO}_{3}$ (65\%) (Fisher Chemical, UK), perchloric acid $-\mathrm{HClO}_{4}(65 \%)$, hydrochloric acid $-\mathrm{HCl}$, sodium hydroxide - $\mathrm{NaOH}$, sulfanilic acid, $\mathrm{N}$ - (1-naphthyl) amine (Sigma-Aldrich, USA), sodium nitrate $\mathrm{NaNO}_{3}$, sodium phosphate - $\mathrm{Na}_{2} \mathrm{HPO}_{4}$, glycerol (Merck, Germany), Fe standard solution (AccuStandard, USA), sodium pentobarbital Vetanarcol $(0.162 \mathrm{~g} / \mathrm{mL})$ (Werfft - Chemie, Austria), saline solution (0.9\% w/v) and deionized water (Hospital Pharmacy Military Medical Academy, Belgrade, Serbia).

\section{Analysis of iron}

Brain tissue samples (around 1g) were mineralized in a mixture of concentrated $\mathrm{HNO}_{3}$ and $\mathrm{HClO}_{4}(4: 1, \mathrm{v} / \mathrm{v})$, heated at temperature between $250{ }^{\circ} \mathrm{C}$ and $300{ }^{\circ} \mathrm{C}$, till dryness and diluted up to $10 \mathrm{~mL}$ with $0.1 \mathrm{M} \mathrm{HNO}_{3}$. The concentrations of Fe were analyzed by inductive coupled atomic absorption spectrometry (IC-AAS, Analyst 200, PerkinElmer), using air-acetylene flame. Standard solutions of Fe were prepared according to the PerkinElmer Pure Atomic Spectroscopy Standards guidelines (NIST traceable CRM, Perkin-Elmer Corporation, USA and Merck - Germany). The absorption wavelength was $305.91 \mathrm{~nm}$.

\section{Superoxide anion radical measurement}

Quantification of $\mathrm{O}_{2}^{--}$was based on nitrobluetetrazolium (NBT) reduction by $\mathrm{O}_{2}^{--}$to yellow colored monoformazan, which absorbance was measured at $550 \mathrm{~nm}$ [21].

\section{Nitrate measurement}

After deproteinization, concentration of nitrates $\left(\mathrm{NO}_{3}{ }^{-}\right.$, the final metabolic product of all RNS) was calculated 
as the difference between two sets of measurements with Griess reagent $(1.5 \%$ sulfanilamide in $1 \mathrm{~mol}$ $\mathrm{HCl}$ plus $0.15 \% \mathrm{~N}$-(1-naphthyl) ethylendiamine dihydrochloride in distilled water), before (only $\mathrm{NO}_{2}^{-}$was measured) and after the addition of cadmium, which reduces $\mathrm{NO}_{3}^{-}$into $\mathrm{NO}_{2}^{-}\left(\mathrm{NO}_{2}^{-}+\mathrm{NO}_{3}^{-}\right.$were measured) [22] . The measurements were performed spectrophotometrically at $492 \mathrm{~nm}$. The results were expressed as $\mathrm{nmol} \mathrm{NO}{ }_{3}^{-} / \mathrm{mg}$ protein.

\section{Protein determination}

The Lowry method was used for protein measurement in rat vulnerable brain regions (VBR) homogenates [23].

\section{Statistical analysis}

One-way ANOVA and post-hoc Dunnett's $C$ tests were used (software GraphPad Prism, version 5.01) for statistical data analysis. Values were presented as average \pm STDEV. Differences were considered statistically significant for $\mathrm{p}<0.05$.

\section{RESULTS}

Decrease of brain Fe concentrations was observed in all experimental groups: MZC, $2 \mathrm{~Gy}$ and $\mathrm{MZC}+10 \mathrm{~Gy}$ $(p<0.01)$; 10Gy $(p<0.05)$ and $M Z C+2 G y \quad(p<0.001)$, compared to the controls. Also, lower Fe was found in $M Z C+2 G y$ and $M Z C+10 G y(p<0.05)$ groups than in corresponding irradiated groups, 2Gy and 10Gy (Figure 1).

\section{Iron}

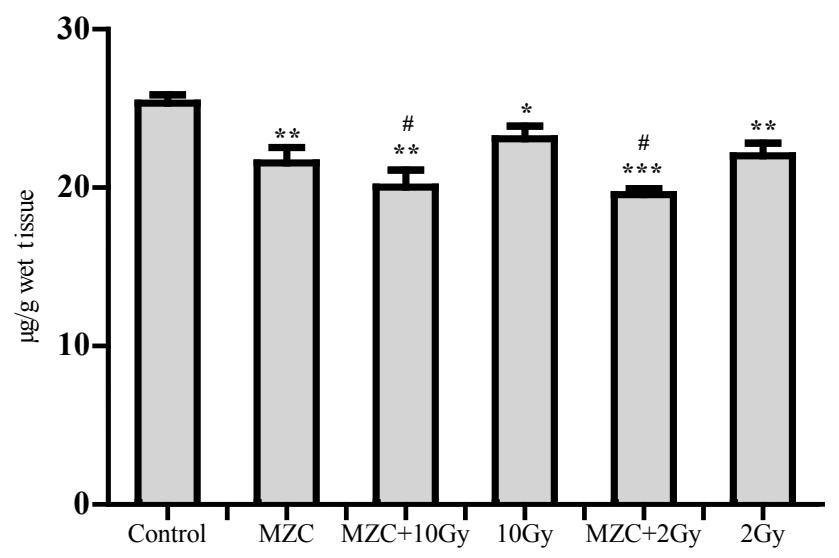

Figure 1. Brain iron in the experimental groups. Brain $\mathrm{Fe}(\mu \mathrm{g}$ $\mathrm{Fe} / \mathrm{mg}$ wet tissue) concentrations are presented as means \pm $\mathrm{SD}$, for 10 animals/group. Differences were considered statistically significant at: ${ }^{*}, \mathrm{p}<0.05,{ }^{* *}, \# \mathrm{p}<0.01$ and $^{* * *} \mathrm{p}<0.001$ ( $^{*}$-compared to control, \#- compared to MZC group). One-way ANOVA, Dunnett's $C$ test were used for statistical analysis.

Decrease of $\mathrm{O}_{2}^{--}$was accomplished in MZC group (in: cerebellum $(p<0.001)$, hippocampus and cortex $(p<0.01))$. Almost identical increase was accomplished in 2Gy (in: cerebellum $(p<0.05)$ and cortex $(p<0.001)$ ), $M Z C+2 G y$ (in: hippocampus and cortex $(p<0.01))$ and MZC+10Gy (in: cortex $(p<0.01)$ ) groups (Figure 2 ).

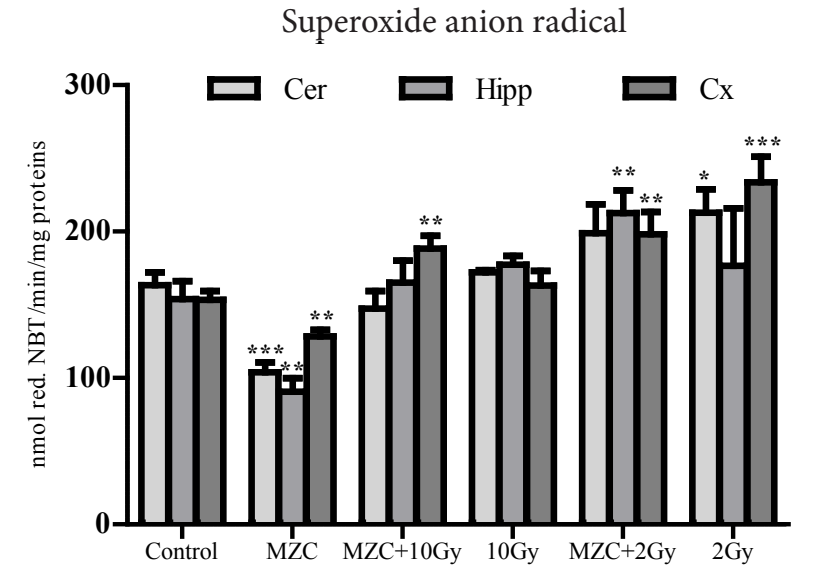

Figure 2. Superoxide anion radical in selective vulnerable brain regiones of the treated rats. Superoxide anion radical, expressed as $\mathrm{nmol}$ red. NBT/min/ $\mathrm{mg}$ protein, was tested in VBRs: cerebellum (Cer), hippocampus (Hipp) and cortex (Cx). Values are presented as means \pm SD, for 10 animals/group. Differences were considered statistically significant at: ${ }^{*} . \# p<0.05,{ }^{* *}, \# \#<0.01$ and ${ }^{* * *} p<0.001{ }^{*}$-compared to control, \#-compared to MZC group). One-way ANOVA, Dunnett's C test were used for statistical analysis.

Significant increase of $\mathrm{NO}_{3}{ }^{-}$was reached in the experimental groups, as follows: 10Gy group (in: cerebellum $(p<0.05)$, hippocampus $(p<0.001)$ and cortex $(p<0.001))$; MZC+10Gy (in: hippocampus $(p<0.05)$ and cortex $(p<0.001))$; and 2Gy (in: hippocampus $(p<0.01))$. Contrary, $\mathrm{NO}_{3}{ }^{-}$decline was documented in: MZC group (in: cerebellum and hippocampus $(p<0.01)$ and cortex $(p<0.001)) ; 2 G y$ (in: cerebellum $(p<0.001)$ and cortex $(p<0.01)$ ); and MZC+2Gy group (in: cerebellum and cortex $(\mathrm{p}<0.001))$. In $\mathrm{MZC}+2 \mathrm{~Gy}$ group, $\mathrm{NO}_{3}{ }^{-}$was lower in hippocampus $(p<0.01)$ and cortex $(p<0.05)$ compared to $2 \mathrm{~Gy}$ group (Figure 3 ).

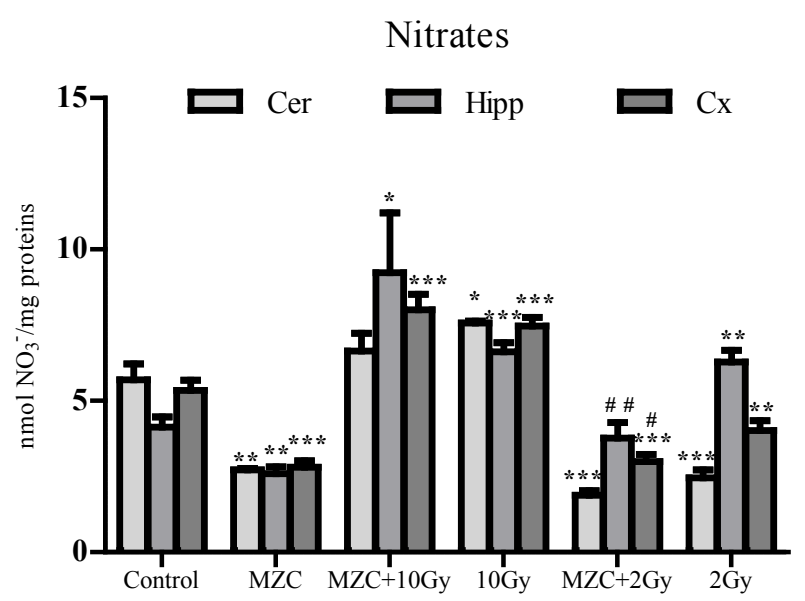

Figure 3. Nitrates in selective vulnerable brain regiones of rats exposed to zeolite. Nitrates $\left(\mathrm{NO}_{3}^{-}: \mathrm{nmol} \mathrm{NO}_{3}^{-} / \mathrm{mg}\right.$ proteins), the final metabolic product of RNS, were measured in VBRs: cerebellum (Cer), hippocampus (Hipp) and cortex (Cx). Values are presented as means \pm SD, for 10 animals/group. Differences were considered statistically significant at: *.\#p $<0.05$, ${ }^{* *}, \#$ p $<0.01$ and ${ }^{* * *} p<0.001$ ( $^{*}$-compared to control, " -compared to MZC group). One-way ANOVA, Dunnett's $C$ test were used for statistical analysis. 
Stanojević et al., Zeolite pretreatment accomplishes partial brain radioprotective role by reducing iron and oxidative ...

\section{DISCUSSION}

Zeolite reversibly binds gases, such as $\mathrm{O}_{2}$ and $\mathrm{NO}$, as well as other nutriments, including metals (i.e. Fe) within GIT [24]. Reduced bioavailability of Fe, ROS and RNS in rats on $5 \%$ MZC supplemented diet during four-week diet regimen imposed a systemic effect, documented by the decreased brain levels of the aforementioned substances. Moreover, according to our results, MZC imposed a partial radioprotective role against brain OS/NS, induced by lower doses of ionizing irradiation (2Gy) in rats (Figures 1-3).

We confirmed positive association between reduced brain ROS and RNS and lower brain Fe concentrations in MZC treated rats. These occurrences confirmed that reduced bioavailability of $\mathrm{Fe}, \mathrm{O}_{2}$ and $\mathrm{NO}$ is followed by a systemic drop of $\mathrm{Fe}, \mathrm{ROS}$ and RNS.

The brain has high levels of $\mathrm{O}_{2}$, transitional metals and polyunsaturated fatty acids and therefore is particularly susceptible to OS [25]. Excessive amounts of ROS and RNS cause OS in all neurons, yet, the vulnerability of neurons to OS varies from one brain region to another, as well as within the same brain region. Although the hippocampal regions $C A 1$ and $C A 3$ are next to each other and are composed of morphologically similar pyramidal neurons, there are differences in their sensitivity to OS. When exposed to pro-oxidative substances, the neurons in the CA1 region suffer massive cell death while those in CA3 mostly survive [26, 27]. Also, significant differences in vulnerability to OS of cerebellar and cortical neurons are documented. Exposed to some OS-inducing agents, such as paraquat, or conditions involving OS, such as ischemia and re-oxygenation, extensive death of neurons in the cerebellum, but not in the cerebral cortex was observed [25].

Overproduction of ROS, including $\mathrm{O}_{2}{ }^{-}, \mathrm{H}_{2} \mathrm{O}_{2}, \mathrm{HO}$ and others, can be triggered by different stimuli, including metabolism of endo- and exogenous compounds in the presence of $\mathrm{O}_{2}$, Fenton-like reactions, ionizing radiation, etc. Oxidative stress development assumes time and spatial spreading of free radical chain reactions in living organisms. In the Fenton reaction, a low-valent transition metal (such as $\mathrm{Fe}^{2+}$ ) reacts with $\mathrm{H}_{2} \mathrm{O}_{2}$ and produces $\mathrm{HO}$; which instantly oxidatively damages various classes of essential biomolecules such as lipids, proteins and nucleic acids [28, 29]. According to our results, reduced brain Fe level is associated with lower concentrations of $\mathrm{O}_{2}^{--}$(Figures 1, 2).

Keeping the homeostasis of NO sustained throughout all body organ systems is immensely important, considering its regulatory role in many physiological processes. However, healthy blood vessel endothelium is defined by the ability to produce NO [30]. Spontaneous reactions between $\mathrm{NO}$ radical (NO) and $\mathrm{O}_{2}^{-{ }^{-}}$results in $\mathrm{ONOO}^{-}$production. Peroxynitrite is an extremely harmful molecule, blamed for atherosclerotic and other NS associated diseases [31].

In relation to this, MZC capability to reduce OS, as well NS in the body, including brain, was anticipated
(Figures 2, 3). Decreased concentrations of $\mathrm{O}_{2}{ }^{--}$and $\mathrm{NO}_{3}{ }^{-}$in all examined brain regions of rats on MZC supplemented diet can be explained by the ability of zeolites to bind transition metals (including metals participating in Fenton reaction, such as Fe) in the alimentary tract and reduce their availability to other organs. Very few studies on zeolite pointed at its indirect, antioxidant effect, confirmed by suppressed lipid peroxidation [5, 32].

However, ionizing radiation can alter molecules within the cells, both directly and indirectly, affecting cell viability. Radiation energy absorbed by tissues and fluids leads to radiolysis of water and biomolecules, resulting in consequent OS and NS development [28, 33, 34].

Human population can be exposed to the dose range of 1-10Gy during radiation therapy treatment or as the result of radiation accidents or nuclear/radiological terrorism [35].

According to our results, a higher irradiation dose caused large elevation of RNS in all examined brain regions of treated rats, while at lower doses elevation of RNS was noticed only in hippocampus. This is consistent with the results of previous studies that confirm that hippocampus is one of the most sensitive brain regions to OS/NS. Radioprotective effect of MZC against brain NS induced by ionizing radiation was accomplished only at lower dose of 2Gy in hippocampus and cortex, but not in cerebellum (Figure 3 ). This is in line with the results from a recent study indicating that lower doses of irradiation increased blood-brain barrier (BBB) permeability, decreased blood flow and content of antioxidants in the cerebellum, more than in other brain regions, causing OS [36].

Significantly enlarged brain NS was obtained after irradiation with 10Gy regardless of the previous dietary regimen, normal or MZC supplemented (Figure 3 ). This suggests that the antioxidant potential of MZC is not sufficient to reduce brain damage caused by high content of $\mathrm{ONOO}^{-}$produced by the higher irradiation dose.

Herein, we demonstrated that the most resistant VBR structure to OS, initiated by $2 \mathrm{~Gy}$ irradiation was hippocampus (no change of $\mathrm{O}_{2}^{--}$level was noticed), while the most sensitive was cortex (the highest $\mathrm{O}_{2}{ }^{-}$ concentration was observed). This can be explained by the different concentrations of $\mathrm{Cu}$, zinc $(\mathrm{Zn})$ and $\mathrm{Mn}$ within these brain regions. The highest concentrations of these metals were documented in hippocampus $[37,38]$. These metals are cofactors of most important enzymatic antioxidants superoxide dismutases (SODs - CUZnSOD and MnSOD) which catalyze dismutation of $\mathrm{O}_{2}{ }^{--}$to $\mathrm{H}_{2} \mathrm{O}_{2}$. Therefore we can conclude that after exposure to $2 \mathrm{~Gy}$ irradiation concentration of $\mathrm{O}_{2}^{--}$in hippocampus is lower than in other brain regions due to higher total SOD activity in this brain section.

After radiation of $10 \mathrm{~Gy}$, no change in the $\mathrm{O}_{2}{ }^{--}$concentration was observed, contrary to the increased $\mathrm{NO}_{3}{ }^{-}$concentration in all tested brain regions of the ex- 
posed rats. We assumed that $\mathrm{O}_{2}{ }^{--}$spontaneously reacts with $\mathrm{NO}$; producing more potent $\mathrm{ONOO}^{-}$.

Regarding NS, cerebellum was proven to be the most resistant VBR region against NS, initiated by $2 \mathrm{~Gy}$ irradiation (an intense $\mathrm{NO}_{3}{ }^{-}$drop was documented), while hippocampus was the most sensitive. The NS respond of all VBRs was similar at 10Gy (Figures 2, 3). Nitric oxide in the brain is synthetized primarily by neuronal nitric oxide synthase (nNOS). However, in the conditions of exposure to various OS-inducing agents activation of inducible nitric oxide synthase (iNOS) can lead to overproduction of NO. Supraphysiological levels of NO cause apoptosis with resultant decreased regional neuronal function. The sensitivity of iNOS to radiation is probably the highest in the hippocampus compared to other brain structures [39].

\section{CONCLUSION}

Herein, we confirmed that decreased bioavailability of $\mathrm{Fe}, \mathrm{NO}$ and $\mathrm{O}_{2}$ by subacute intake of $\mathrm{MZC}$ resulted in systemic drop of Fe, ROS and RNS, judging by brain $\mathrm{Fe}, \mathrm{ROS}$ and RNS levels in the exposed rats. Zeolite achieved a partial antioxidative effect initiated by a lower dose of ionizing radiation and limited antioxidative effect initiated by a higher irradiation dose in the exposed rats.

Also, the obtained results suggest that there are differences in the sensitivity to radiation between the individual brain structures evaluated by OS/NS development that can be explained by variations in cerebrovascular permeability, content of antioxidant enzymes and transition metals.

\section{CONFLICT OF INTEREST STATEMENT}

The authors disclosed any financial or personal relationships that could inappropriately influence or bias the content of the paper.

\section{ACKNOWLEDGEMENT}

The authors greatly appreciated the courtesy of M. Sadiković, Viridsfarm Ltd for donating MZC, as well as the reviewers' criticisms and helpful suggestions. The study was supported by grants from the Ministry of Education and Science, Republic of Serbia (Project: No. III41018) and by the Ministry of Defense of the Republic of Serbia (Projects No.: MFVMA/6/15-17, MFVMA/04/16-18).

\section{REFERENCES}

1. YurekliY. Removal of heavy metals in wastewater by using zeolite nano-particles impregnated polysulfone membranes. Journal of hazardous materials. 2016; 309:53-64.

2. Yi H, Deng H, Tang X, Yu Q, Zhou X, Liu H. Adsorption equilibrium and kinetics for SO 2, NO, CO 2 on zeolites FAU and LTA. Journal of hazardous materials. 2012; 203:111-7.

3. Wang L, Zhang T, Wen C, Jiang Z, Wang T, Zhou Y. Protective effects of zinc-bearing clinoptilolite on broilers challenged with Salmonella pullorum. Poultry science. 2012; 91(8):1838-45.

4. Zarcovic N, Zarcovic K, Kralj M, Borovic S, Sabolovic S, Blazi MP, et al. Anticancer and antioxidative effects of micronized zeolite clinoptilolite. Anticancer research. 2003; 23(2):1589-96.

5. Pavelic K, Katic M, Sverko V, Marotti T, Bosnjak B, Balog $\mathrm{T}$, et al. Immunostimulatory effect of natural clinoptilolite as a possible mechanism of its antimetastatic ability. Journal of cancer research and clinical oncology. 2002; 128(1):37-44.

6. Wu L, Navrotsky A. Synthesis and thermodynamic study of transition metal ion ( $\mathrm{Mn} \mathrm{2+,} \mathrm{Co} \mathrm{2+,} \mathrm{Cu} \mathrm{2+,} \mathrm{and} \mathrm{Zn} \mathrm{2+)}$ exchanged zeolites $A$ and Y. Physical Chemistry Chemical Physics. 2016; 18(15):10116-22.

7. Rotter I, Kosik-Bogacka D, Dołęgowska B, Safranow K, Lubkowska A, Laszczyńska M. Relationship between the concentrations of heavy metals and bioelements in aging men with metabolic syndrome. International journal of environmental research and public health. 2015; 12(4):3944-61.

8. Lipiński P, Starzyński R, Styś A, Gajowiak A, Staroń R. Heme metabolism as an integral part of iron homeostasis. Postepy higieny i medycyny doswiadczalnej (Online). 2014; 68:557-70.

9. Đukić M, Ninković M, Jovanović M. Oxidative stress-Clinical diagnostic significance. Journal of Medical Biochemistry. 2008; 27(4):409-25.

10. Spitz DR, Azzam El, Li JJ, Gius D. Metabolic oxidation/ reduction reactions and cellular responses to ionizing radiation: a unifying concept in stress response biology. Cancer and Metastasis Reviews. 2004; 23(3-4):311-22.

11. Azzam El, Jay-Gerin J-P, Pain D. Ionizing radiation-induced metabolic oxidative stress and prolonged cell injury. Cancer letters. 2012; 327(1):48-60.

12. Al-Nimer MS, Ali NH. Assessment of nitrosative stress and lipid peroxidation activity in asymptomatic exposures to medical radiation: The bystander effect of ionizing radiation. International Journal of Applied and Basic Medical Research. 2012; 2(1):48.

13. Sprynskyy M, Buszewski B, Terzyk AP, Namieśnik J. Study of the selection mechanism of heavy metal $(\mathrm{Pb} 2+, \mathrm{Cu} 2+$, $\mathrm{Ni} 2+$, and $\mathrm{Cd} 2+$ ) adsorption on clinoptilolite. Journal of colloid and interface science. 2006; 304(1):21-8.

14. Katsoulos P, Roubies N, Panousis N, Karatzias H. Effects of long-term feeding dairy cows on a diet supplemented with clinoptilolite on certain serum trace elements. Biological trace element research. 2005; 108(1):137-45.

15. Ortatatli $M$, Oğuz H, Hatipoğlu F, Karaman M. Evaluation of pathological changes in broilers during chronic aflatoxin (50 and $100 \mathrm{ppb}$ ) and clinoptilolite exposure. Research in veterinary science. 2005; 78(1):61-8.

16. Kanyılmaz M, Tekelioğlu N, Sevgili $H$, Uysal R, Aksoy A. Effects of dietary zeolite (clinoptilolite) levels on growth 
performance, feed utilization and waste excretions by gilthead sea bream juveniles (Sparus aurata). Animal Feed Science and Technology. 2015; 200:66-75.

17. Alinezhad S, Faridi M, Falahatkar B, Nabizadeh R, Davoodi D. Effects of nanostructured zeolite and aflatoxin B1 in growth performance, immune parameters and pathological conditions of rainbow trout Oncorhynchus mykiss. Fish \& shellfish immunology. 2017; 70:648-55.

18. Ghasemi Z, Sourinejad I, Kazemian H, Rohani S. Application of zeolites in aquaculture industry: a review. Reviews in Aquaculture. 2018; 10(1):75-95.

19. Council NR. Guide for the care and use of laboratory animals: National Academies Press; 2010.

20. Kassayova M, Ahlersova E, Ahlers I. Two-phase response of rat pineal melatonin to lethal whole-body irradiation with gamma rays. Physiological research. 1999; 48:22730.

21. Anderson RS, Oliver LM, Brubacher LL. Superoxide anion generation by Crassostrea virginica hemocytes as measured by nitroblue tetrazolium reduction. Journal of Invertebrate Pathology. 1992; 59(3):303-7.

22. Navarro-Gonzálvez JA, García-Benayas C, Arenas J. Semiautomated measurement of nitrate in biological fluids. Clinical chemistry. 1998; 44(3):679-81.

23. Lowry $\mathrm{OH}$, Rosebrough NJ, Farr AL, Randall RJ. Protein measurement with the Folin phenol reagent. Journal of biological chemistry. 1951; 193(1):265-75.

24. Murkani M, Nasrollahi M, Ravanbakhsh M, Bahrami P, Jaafarzadeh Haghighi Fard N. Evaluation of natural zeolite clinoptilolite efficiency for the removal of ammonium and nitrate from aquatic solutions. 2015; 2(1):17-22.

25. Wang X, Michaelis EK. Selective neuronal vulnerability to oxidative stress in the brain. Frontiers in aging neuroscience. 2010; 2:12.

26. Sarnowska A. Application of organotypic hippocampal culture for study of selective neuronal death. Folia neuropathologica. 2002; 40(2):101-6.

27. Wang Q, Tompkins KD, Simonyi A, Korthuis RJ, Sun AY, Sun GY. Apocynin protects against global cerebral ischemiareperfusion-induced oxidative stress and injury in the gerbil hippocampus. Brain research. 2006; 1090(1):182-9.

28. Nauser T, Koppenol WH, Gebicki JM. The kinetics of oxidation of GSH by protein radicals. Biochemical Journal. 2005; 392(3):693-701.
29. Gebicki JM, Nauser T, Domazou A, Steinmann D, Bounds $\mathrm{PL}$, Koppenol WH. Reduction of protein radicals by GSH and ascorbate: potential biological significance. Amino acids. 2010; 39(5):1131-7.

30. Pierini $D$, Bryan NS. Nitric oxide availability as a marker of oxidative stress. Advanced Protocols in Oxidative Stress III. 2015; 63-71.

31. Djukic M, Jovanovic MC, Ninkovic M, Vasiljevic I, Jovanovic $M$. The role of nitric oxide in paraquat-induced oxidative stress in rat striatum. Annals of Agricultural and Environmental Medicine. 2007; 14(2):247-52.

32. Ipek H, Avci M, Aydilek N, Yerturk M. The effect of zeolite on oxidant/antioxidant status in healthy dairy cows. Acta Veterinaria Brno. 2012; 81(1):43-7.

33. LaVerne JA. OH radicals and oxidizing products in the gamma radiolysis of water. Radiation research. 2000; 153(2):196-200.

34. Nakagawa K, Nishio T. Electron paramagnetic resonance investigation of sucrose irradiated with heavy ions. Radiation research. 2000; 153(6):835-9.

35. Coleman CN, Blakely WF, Fike JR, MacVittie TJ, Metting NF, Mitchell JB, et al. Molecular and cellular biology of moderate-dose (1-10 Gy) radiation and potential mechanisms of radiation protection: report of a workshop at Bethesda, Maryland, December 17-18, 2001. Radiation research. 2003; 159(6):812-34.

36. Zhou K, Boström M, Ek CJ, Li T, Xie C, Xu Y, et al. Radiation induces progenitor cell death, microglia activation, and blood-brain barrier damage in the juvenile rat cerebellum. Scientific reports. 2017; 7:46181.

37. Dobrowolska J, Dehnhardt M, Matusch A, Zoriy M, Palomero-Gallagher N, Koscielniak P, et al. Quantitative imaging of zinc, copper and lead in three distinct regions of the human brain by laser ablation inductively coupled plasma mass spectrometry. Talanta. 2008; 74(4):717-23.

38. Takeda A, Sawashita J, Okada S. Biological half-lives of zinc and manganese in rat brain. Brain research. 1995; 695(1):53-8.

39. Zhou L, Zhu D-Y. Neuronal nitric oxide synthase: structure, subcellular localization, regulation, and clinical implications. Nitric oxide. 2009; 20(4):223-30. 
Boban Stanojević ${ }^{1}$, Mirjana Đukić2*, Ivana Stevanović3 Milica Ninkovićs, Ana Đurić2, Borko Gobeljić ${ }^{2}$, Milan Apostolović ${ }^{4}$, Ana Pantelić5, Goran Zebić6, Lidija Todorović1, Tijana Bojićn , Kiril Savovski ${ }^{1}$

1 Univerzitet u Beogradu - Institut za nuklearne nauke "Vinča", Laboratorija za radiobiologiju i molekularnu genetiku 080, Beograd, Srbija

2 Univerzitet u Beogradu Farmaceutski fakultet, Katedra za toksikologiju, Beograd, Srbija

${ }^{3}$ Univerzitet odbrane - Medicinski fakultet, Vojnomedicinska akademija, Institut za medicinska istraživanja, Beograd, Srbija

${ }^{4}$ Univerzitet u Beogradu - Medicinski fakultet, Institut za ortopedskohirurške bolesti „Banjica”, Beograd, Srbija

${ }^{5}$ Univerzitet u Beogradu - Naučna ustanova, Institut za hemiju, tehnologiju i metalurgiju, Centar za hemiju, Beograd, Srbija

${ }^{6}$ Univerzitet u Beogradu Poljoprivredni fakultet, Katedra za tehnologiju hrane, Beograd-Zemun, Srbija

* Corresponding author:

Mirjana Đukić, Professor

Faculty of Pharmacy, Belgrade

\section{Predtretman zeolitom ostvaruje delimično radioprotektivni efekat na mozak smanjujući gvožđe i oksidativni/nitrozativni stres kod pacova}

\section{Kratak sadržaj}

Cilj naše studije je bio da ustanovimo efekat subakutno primenjenog mikronizovanog zeolita [mikronizovanog klinoptilolita (MZC)] na moždani status gvožđa $(\mathrm{Fe})$ i reaktivnih vrsta kiseonika i azota (eng. reactive oxygen and nitrogen species, ROS, RNS), kao i radioprotektivnu ulogu od moždanog oksidativnog/nitrozativnog stresa (OS/NS) iniciranog pojednačnim dozama jonizujućeg zračenja od 2 ili 10Gray (Gy) kod pacova. Wistar pacovi na četvoronedeljnom režimu normalne ishrane $(n=18)$ i ishrane dopunjene $5 \%$ MZC ( $n=18)$ su interno podeljeni u 3 podgrupe sa po 6 pacova $(n=6)$, a od toga po jedna grupa je bila kontrolna, a druge dve su podvrgnute pojedinačnim dozama zračenja od 2Gy i 10Gy. Tako, imali smo na normalnoj ishrani grupe: C-kontrolna, 2Gy i 10Gy; a na ishrani dopunjenoj 5\% MZC: MZC, MZC+2Gy i $M Z C+10 G y$ grupe. Koncentracije nitrata (krajnji RNS metabolit) i superoksid anjon radikala $\left(\mathrm{O}_{2}{ }^{-}\right)$(inicijalni $\left.\mathrm{ROS}\right)$ su merene $u$ homogenatima selektivno osetljivih moždanih struktura (mali mozak, hipokampus i korteks), dok je Fe mereno u celom mozgu pacova. Rezultati pokazuju značajno smanjenje Fe u MZC i MZC+2Gy/10Gy grupama; smanjenje $\mathrm{O}_{2}^{--}$i nitrata u MZC grupi; gotovo identičan pad $\mathrm{O}_{2}^{--}$u 2Gy i MZC+2Gy grupama; i povećanje nitrata u 10Gy i MZC+10Gy grupama. Potvrdili smo da subakutni pretretman pacova MZC doprinosi delimičnom moždanom radioprotektivnom učinku kod pacova jednokratno izloženih zračenju od $2 \mathrm{~Gy}$ ili 10Gy, verovatno usled smanjenjenog OS/NS i Fe.

Ključne reči: mozak, gvožđe, jonizujuće zračenje, nitrozativni stres, oksidativni stres, zeolit $(M Z C)$ 